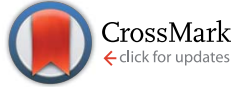

Cite this: RSC Adv., 2016, 6, 65119

Received 16th June 2016

Accepted 3rd July 2016

DOI: $10.1039 / c 6 r a 15638 j$

www.rsc.org/advances

\title{
A practical and efficient synthesis of methyl levulinate from cellulosic biomass catalyzed by an aluminum-based mixed acid catalyst system $\uparrow$
}

\begin{abstract}
K. Tominaga, ${ }^{\text {*ab }}$ K. Nemoto, ${ }^{a}$ Y. Kamimura, ${ }^{a}$ A. Yamada, ${ }^{c}$ Y. Yamamoto ${ }^{c}$ and K. Sato ${ }^{a b}$
Methyl levulinate is a promising building block which can be derived from cellulosic biomass. In this paper, a combination of aluminum compounds and organic sulfonic acids was found to be an efficient catalyst system for direct methyl levulinate synthesis from both microcrystalline cellulose and wood powder. Electrospray ionization mass analysis revealed the formation of aluminum sulfonate complexes in the reaction solution. The reaction properties of this catalyst system suggested that cooperative catalysis of aluminum sulfonates and organic sulfonic acids in methanol was responsible for the efficient formation of methyl levulinate.
\end{abstract}

\section{Introduction}

Recently, levulinic acid (LA) has attracted much attention because it has been recognized as a key building block that can be derived from cellulosic biomass. ${ }^{1,2}$ Specialty chemicals, such as agricultural chemicals, ${ }^{3}$ a methyl methacrylate substitute, ${ }^{4}$ and a bisphenol A substitute, ${ }^{5}$ as well as commodity chemicals, such as butene, ${ }^{6}$ succinic acid, ${ }^{7}$ and adipinic acid, ${ }^{8}$ can be synthesized from LA.

Many synthesis methods of LA from cellulose have been reported. Conventionally, sulfuric acid is used for this reaction, but a much larger stoichiometric amount of sulfuric acid compared to cellulose is required and the yield of LA is between 60 and $70 \%$ based on the glucose units in cellulose. ${ }^{9}$

To replace sulfuric acid with more efficient acids that can act even at lower amounts, many kinds of acid catalysts such as metal salts, ${ }^{\mathbf{1 0}}$ heteropolyacids, ${ }^{\mathbf{1 1}}$ and solid acids ${ }^{\mathbf{1 2}}$ have been examined to date. Among the metal salts, $\mathrm{CrCl}_{3}$ has reported to be the most effective in forming LA from cellulose (yields of $67 \%$ after the reaction at $200{ }^{\circ} \mathrm{C}$ for $3 \mathrm{~h}$ ), but it was difficult to reuse it because of the formation of a less reactive chromium oxide. ${ }^{10 b}$ As for the heteropolyacids, ionic-liquid-substituted heteropolyacids were found to be effective in forming LA in 63\% yield via the reaction at $140{ }^{\circ} \mathrm{C}$ for $12 \mathrm{~h} .{ }^{11 b}$ Although the catalyst was shown to be reusable for the hydrolysis of cellulose, its

${ }^{a}$ National Institute of Advanced Industrial Science and Technology (AIST), Central 5, 1-1-1 Higashi, Tsukuba, Ibaraki 305-8569, Japan. E-mail: k-tominaga@aist.go.jp

${ }^{b}$ Institute for Catalysis, Hokkaido University, Kita21, Nishi10, Kita-ku, Sapporo, Hokkaido 001-0021, Japan

'Organic Chemistry Research Lab., Ube Industries, Ltd., 1978-5, Kogushi, Ube, Yamaguchi 755-8633, Japan

$\dagger$ Electronic supplementary information (ESI) available. See DOI: 10.1039/c6ra15638j reusability for LA formation remains unclear. Typical solid acids such as Amberlyst and Nafion have also shown catalytic activities for the synthesis of LA from cellulose. ${ }^{12 c}$ The LA yield reached over $60 \%$ when the reaction was carried out in aqueous $\gamma$-valerolactone solvent at $160{ }^{\circ} \mathrm{C}$; however, large amounts of the catalyst, almost the same weight as cellulose, and a long reaction time of $16 \mathrm{~h}$ were required. Therefore, a more efficient and recyclable catalyst system for LA synthesis from cellulose is eagerly anticipated.

Cellulose has very unique properties; its crystal structure is strongly bonded with both hydrogen bonds and van der Waals forces. ${ }^{13}$ In order to decompose cellulose to glucose, both types of bonds have to be dissociated efficiently. The following two hypotheses can therefore be postulated: (1) the optimum acid for the decomposition of cellulose to glucose is different to that for the transformation of glucose to LA, and (2) because cellulose has a strong affinity to water, the reaction should be carried out in protonic organic solvents.

Based on these hypotheses, we developed an effective catalyst system for the synthesis of methyl levulinate (MeLev) in methanol. ${ }^{14}$ This catalyst system consists of two different kinds of acids, a Brønsted and Lewis acid; it has been demonstrated that the former mainly catalyzes the solvolysis of cellulose and the latter the transformation of sugar to MeLev. As a result, the yield of MeLev reached 75\% when the reaction was carried out at $180{ }^{\circ} \mathrm{C}$ for $5 \mathrm{~h}$ and when $\mathrm{In}(\mathrm{OTf})_{3}$ and 2-naphthalenesulfonic acid (2-NSA) were used as the catalyst system. This catalyst system can also be used for the direct synthesis of MeLev from wood biomass; the yield of MeLev was $97 \%$ based on the glucose units of cellulose in cedar powder.

However, both indium and trifluoromethanesulfonic acid are expensive materials and the practical application of this catalyst system has therefore been limited. In this paper, we report an improved catalyst system for the synthesis of MeLev 
from both cellulosic and wood biomass using inexpensive and easily available aluminum compounds in place of rare metals or trifluoromethanesulfonic acid.

\section{Experimental}

All reagents were of research grade and used without further purification. $\mathrm{Al}(\mathrm{acac})_{3}, \mathrm{AlBr}_{3}$, and $\mathrm{AlCl}_{3}$ were purchased from Wako Pure Chemical Industry. $\mathrm{Al}(\mathrm{OH})_{3}, \mathrm{Al}_{2}\left(\mathrm{SO}_{4}\right)_{3}, \mathrm{AlI}_{3}, \mathrm{In}(\mathrm{OTf})_{3}$, 1-pyrenesulfonic acid (1-PSA), and microcrystalline cellulose $(<20 \mu \mathrm{m})$ were purchased from Sigma-Aldrich. $\mathrm{Al}(\mathrm{OEt})_{3}$, benzenesulfonic acid (BSA), and 2-naphthalenesulfonic acid (2-NSA) were purchased from Tokyo Chemical Industry. $\mathrm{Al}(\mathrm{OAc})_{3}, p$ toluenesulfonic acid (PTSA), glucose, and methanol were purchased from Kishida Chemical. 5-Methoxymethylfurfural (MMF) prepared according to a literature procedure. ${ }^{15}$ Wood powders were supplied by Nippon Paper Industries. The content of cellulose, hemicellulose, and lignin in the wood powders were determined using a conventional procedure. ${ }^{16}$ These wood powders were cutter-milled and sieved to decrease the particle size in the range of 100 to $425 \mu \mathrm{m}$.

In a typical experiment for MeLev synthesis from cellulose, to a $50 \mathrm{~mL}$ stainless steel autoclave equipped with a magnetic stirring bar, microcrystalline cellulose $(2.5 \mathrm{mmol}$ as glucose units), Al precursor (0.02 $\mathrm{mmol}), p$-toluenesulfonic acid (0.20 $\mathrm{mmol})$, and methanol $(20.0 \mathrm{~mL})$ were added and the apparatus was purged with $\mathrm{N}_{2}(0.5 \mathrm{MPa})$. Then, the apparatus was heated to $180{ }^{\circ} \mathrm{C}$ and maintained at this temperature for $5 \mathrm{~h}$ with stirring. After the apparatus was cooled to room temperature and depressurized, the reaction solution was recovered and analyzed by high-performance liquid chromatography (HPLC).

HPLC analyses were carried out on a JASCO LC-2000Plus system. The quantitative analysis of sugars was performed with an Aminex HPX-87H column $(250 \times 4.0 \mathrm{~mm}$ I.D., Bio-Rad Laboratories, Inc.) using a $7.5 \mathrm{mM}$ aqueous solution of sulfuric acid as the mobile phase and 2-methyl tetrahydrofuran as the internal standard. The quantitative analysis of MeLev was performed on a Scherzo SS-C18 column $(250 \times 4.0 \mathrm{~mm}$ I.D., Imtakt Corp.) using a 20 vol\% aqueous solution of methanol containing $10 \mathrm{mM}$ formic acid as the mobile phase and 2-methyl tetrahydrofuran as the internal standard.

Electrospray ionization mass spectrometry (ESI-MS) analysis was carried out on a Waters ZQ-2000 spectrometer. The needle and cone voltage were $+4.0 \mathrm{kV}$ and $50 \mathrm{~V}$, respectively. The sample solution was filtered and directly introduced into the apparatus at an infusion rate of $20 \mu \mathrm{L} \mathrm{min}^{-1}$.

\section{Results and discussion}

Representative results of MeLev syntheses from microcrystalline cellulose are summarized in Table 1 . When only PTSA was used as the acid catalyst, MeLev was obtained in $47 \%$ yield, together with MMF in 2\% yield, and sugars in 13\% yield after the reaction at $180{ }^{\circ} \mathrm{C}$ for $5 \mathrm{~h}$ (entry 1 ). The reaction solution was brown in color and contained a small amount of colloidal particles which appeared to be humin. As an aluminum compound, $\mathrm{Al}(\mathrm{acac})_{3}$ is air and moisture stable, and thus easily
Table 1 MeLev synthesis from microcrystalline cellulose catalyzed by mixed acid systems ${ }^{a}$

\begin{tabular}{|c|c|c|c|c|c|}
\hline \multirow[b]{2}{*}{ Entry } & \multirow[b]{2}{*}{ Lewis acid } & \multirow{2}{*}{$\begin{array}{l}\text { Brønsted } \\
\text { acid }\end{array}$} & \multicolumn{3}{|c|}{ Yield $^{b} / \%$} \\
\hline & & & MeLev & MMF & Sugars $^{c}$ \\
\hline 1 & - & PTSA & 47 & 2 & 13 \\
\hline 2 & $\mathrm{Al}(\mathrm{acac})_{3}$ & - & - & - & 1 \\
\hline 3 & $\mathrm{Al}(\mathrm{acac})_{3}$ & PTSA & 72 & 1 & 1 \\
\hline 4 & $\mathrm{Al}(\mathrm{OH})_{3}$ & PTSA & 64 & - & - \\
\hline 5 & $\mathrm{Al}(\mathrm{OAc})_{3}$ & PTSA & 66 & - & 4 \\
\hline 6 & $\mathrm{Al}(\mathrm{OEt})_{3}$ & PTSA & 69 & 1 & 1 \\
\hline 7 & $\mathrm{Al}_{2}\left(\mathrm{SO}_{4}\right)_{3}$ & PTSA & 63 & - & - \\
\hline 8 & $\mathrm{AlI}_{3}$ & PTSA & 67 & 1 & 1 \\
\hline 9 & $\mathrm{AlBr}_{3}$ & PTSA & 64 & 1 & 1 \\
\hline 10 & $\mathrm{AlCl}_{3}$ & PTSA & - & - & 8 \\
\hline 11 & $\mathrm{Al}(\mathrm{OH})_{3}$ & BSA & 61 & 1 & - \\
\hline 12 & $\mathrm{Al}(\mathrm{OH})_{3}$ & 2-NSA & 74 & - & - \\
\hline 13 & $\mathrm{Al}(\mathrm{OH})_{3}$ & 1-PSA & 49 & 4 & 16 \\
\hline 14 & $\operatorname{In}(\mathrm{OTf})_{3}$ & PTSA & 73 & - & 1 \\
\hline
\end{tabular}

${ }^{a}$ Conditions: Lewis acid $(0.02 \mathrm{mmol})$, Brønsted acid $(0.20 \mathrm{mmol})$, microcrystalline cellulose ( $405 \mathrm{mg}, 2.5 \mathrm{mmol}$ as glucose units), $\mathrm{MeOH}$ $(20.0 \mathrm{~mL}), \mathrm{N}_{2}(0.5 \mathrm{MPa}), 180{ }^{\circ} \mathrm{C}, 5 \mathrm{~h} .{ }^{b}$ HPLC yields based on the glucose units in cellulose. ${ }^{c}$ Total amount of fructose, glucose, and $\alpha$ methylglycoside.

handled. When only $\mathrm{Al}(\mathrm{acac})_{3}$ was used as the catalyst, the reaction barely proceeded and white cellulose powder remained in the reaction solution because its acidity was too weak to solvolyze cellulose (entry 2). However, when $\mathrm{Al}(\text { acac) })_{3}$ was used in combination with PTSA, cellulose was efficiently converted to MeLev in $72 \%$ yield (entry 3 ). As observed in entry 1 , the reaction solution contained a small amount of colloidal humin. The yield of MeLev was almost the same as that obtained with our previous catalyst system of $\operatorname{In}(\mathrm{OTf})_{3}$ and PTSA (entry 14).

As for the effects of $\mathrm{Al}$ precursors, other common $\mathrm{Al}$ salts such as $\mathrm{Al}(\mathrm{OH})_{3}, \mathrm{Al}(\mathrm{OAc})_{3}, \mathrm{Al}(\mathrm{OEt})_{3}, \mathrm{Al}_{2}\left(\mathrm{SO}_{4}\right)_{3}, \mathrm{AlI}_{3}$, and $\mathrm{AlBr}_{3}$ gave slightly lower MeLev yields than $\mathrm{Al}\left(\right.$ acac) ${ }_{3}$ (entries 3-9), while $\mathrm{AlCl}_{3}$ significantly inhibited the solvolysis of cellulose and white cellulose powder remained unreacted (entry 10). This inhibition was specifically caused by $\mathrm{HCl}$ formed from $\mathrm{AlCl}_{3}$ and PTSA; when the reaction shown in entry 1 was carried out in the presence of $0.06 \mathrm{mmol}$ of $\mathrm{HCl}$ (corresponding to $0.02 \mathrm{mmol}$ of $\mathrm{AlCl}_{3}$ ) and $0.2 \mathrm{mmol}$ of PTSA, the solvolysis of cellulose was also inhibited and white cellulose ponder was remained. No such inhibition was observed in the cases of other halide salts and their catalytic activity increased in the order $\mathrm{AlCl}_{3} \ll \mathrm{AlBr}_{3}<$ $\mathrm{AlI}_{3}$.

Among the organic sulfonic acids tested, 2-NSA was the most effective; the yield of MeLev reached 74\% when 2-NSA was used in combination with $\mathrm{Al}(\mathrm{OH})_{3}$ (entries 11-13). The catalytic activity decreased in the order 2-NSA > PTSA > BSA > 1-PSA. Because all these sulfonic acids have almost the same acidity, there must be an optimal aromatic ring size for catalysis in this reaction.

The effect of Al/PTSA ratio is shown in Fig. 1. In the absence of Al salt, MeLev was formed in only moderate yield, while its yield drastically increased with the addition of just a 1/200 molar amount of $\mathrm{Al}(\mathrm{acac})_{3}$ to PTSA. The maximum yield of 


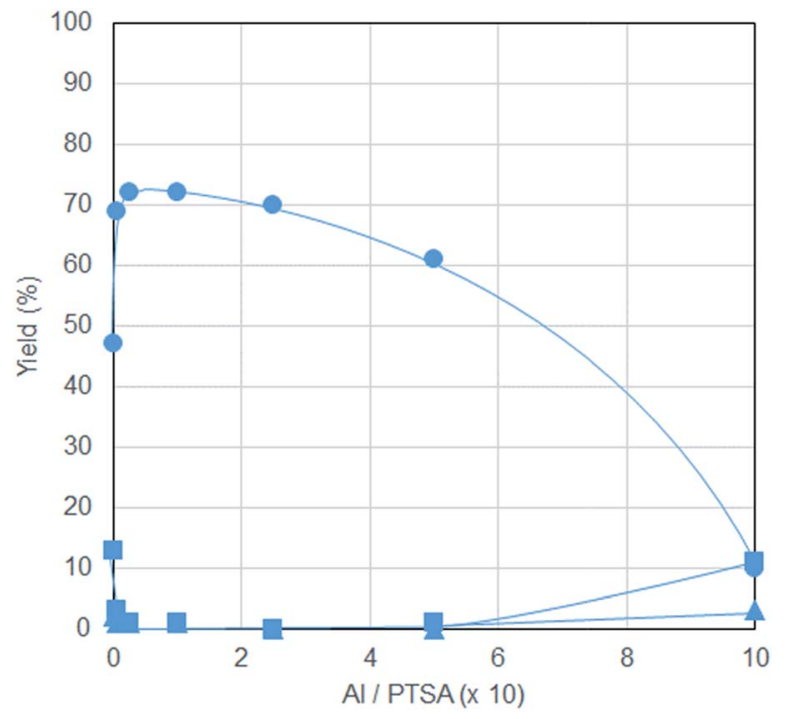

Fig. 1 Effect of Al/PTSA ratio $-=$ MeLev, $\boldsymbol{\Delta}=$ MMF, $\mathbf{\square}=$ sugars Conditions: $\left.\mathrm{Al}_{(\mathrm{acac}}\right)_{3}$ and PTSA (total amount: $0.22 \mathrm{mmol}$ ), microcrystalline cellulose ( $405 \mathrm{mg}, 2.5 \mathrm{mmol}$ as glucose units), $\mathrm{MeOH}$ (20.0 $\mathrm{mL}), \mathrm{N}_{2}(0.5 \mathrm{MPa}), 180{ }^{\circ} \mathrm{C}, 5 \mathrm{~h}$. All the yields were determined by the same method described in Table 1.

MeLev was obtained at Al/PTSA $=1 / 40$. Above this ratio, the yield of MeLev decreased gradually, reaching just $10 \%$ when equimolar amounts of $\mathrm{Al}(\mathrm{acac})_{3}$ and PTSA were used. At this ratio, a significant amount of cellulose powder was observed to be unreacted, probably because almost amount of PTSA bonded to $\mathrm{Al}(\mathrm{acac})_{3}$ to form an $\mathrm{Al}$ sulfonate compound.

The effect of reaction temperature is shown in Fig. 2. MeLev formation proceeded even at $160{ }^{\circ} \mathrm{C}$, while $16 \%$ sugars remained unreacted. The optimum reaction temperature for

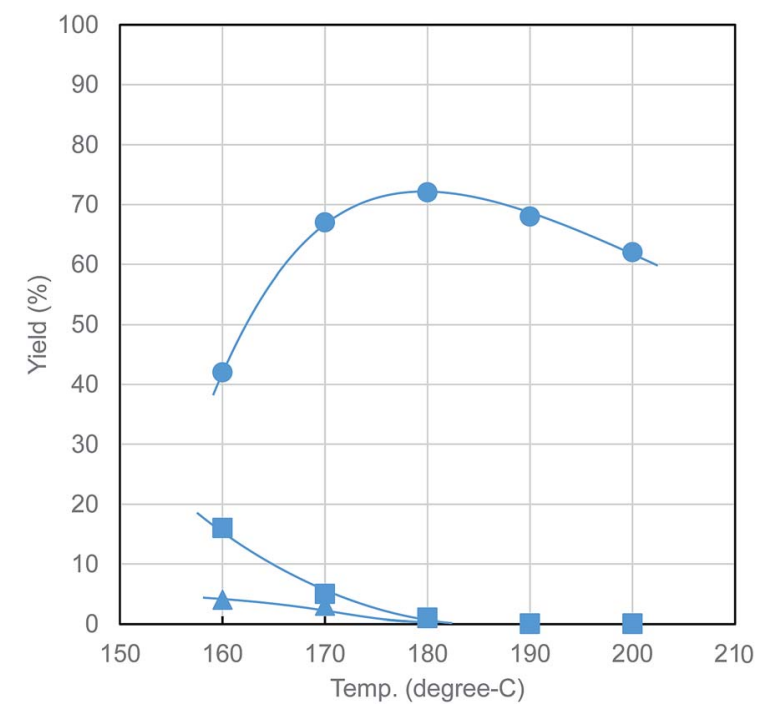

Fig. 2 Effect of reaction temperature $\boldsymbol{0}=$ MeLev, $\mathbf{\Lambda}=$ MMF sugars. Conditions: $\mathrm{Al}(\mathrm{acac})_{3}(0.02 \mathrm{mmol}), \mathrm{PTSA}(0.20 \mathrm{mmol})$, microcrystalline cellulose ( $405 \mathrm{mg}, 2.5 \mathrm{mmol}$ as glucose units), $\mathrm{MeOH}(20.0$ $\mathrm{mL}), \mathrm{N}_{2}(0.5 \mathrm{MPa}), 5 \mathrm{~h}$. All the yields were determined by the same method described in Table 1.
MeLev formation lies at around $180{ }^{\circ} \mathrm{C}$, above which its yield decreases slightly.

The time course of the reaction at $180{ }^{\circ} \mathrm{C}$ (Fig. 3) shows that only small amounts of sugars and MMF were formed in the initial stage, which means that solvolyzed sugars were readily transformed to MMF and then MeLev. The formation of MeLev is almost complete within $3 \mathrm{~h}$.

The catalyst system is recyclable. After distillation of the solvent and products, the residue was recovered and used as the catalyst for the next run, in which the same amount of microcrystalline cellulose as the first run was newly added. As shown in Fig. 4, although the yield of MeLev decreased slightly, it remained above $60 \%$.

In order to investigate the catalyst species in the reaction, the $\mathrm{MeOH}$ solution of $\mathrm{Al}(\mathrm{acac})_{3}$ and PTSA heat-treated at $180{ }^{\circ} \mathrm{C}$ under 0.5 $\mathrm{MPa} \mathrm{N}_{2}$ for $2 \mathrm{~h}$ was analyzed by ESI-MS (Fig. 5). The detected species were as follows: $\mathrm{TsOH}_{2}{ }^{+}$(a, $\left.m / z=173\right), \mathrm{Al}(\mathrm{OTs})$ $\mathrm{H}^{+}(\mathbf{b}, m / z=199), \quad \mathrm{Al}(\mathrm{OTs})(\mathrm{OMe})^{+} \quad(\mathbf{c}, \quad m / z=229)$, $\mathrm{Al}(\mathrm{OTs})(\mathrm{OMe})\left(\mathrm{H}_{2} \mathrm{O}\right)^{+}\left(\mathbf{c}\left(\mathbf{H}_{2} \mathbf{O}\right), m / z=247\right), \mathrm{Al}(\mathrm{OTs})(\mathrm{OMe})(\mathrm{MeOH})^{+}$ $(\mathbf{c}(\mathbf{M e O H}), \quad m / z=261), \operatorname{Al}(\mathrm{OTs})(\mathrm{OMe})(\mathrm{MeOH})\left(\mathrm{H}_{2} \mathrm{O}\right)^{+}\left(\mathbf{c}\left(\mathbf{H}_{2^{-}}\right.\right.$ O)(MeOH), $m / z=279), \operatorname{Al}(\mathrm{OTs})_{2}{ }^{+}(\mathbf{d}, m / z=369), \mathrm{Al}(\mathrm{OTs})_{2}\left(\mathrm{H}_{2} \mathrm{O}\right)^{+}$ $\left(\mathbf{d}\left(\mathbf{H}_{2} \mathbf{O}\right), m / z=387\right), \operatorname{Al}(\mathrm{OTs})_{2}(\mathrm{MeOH})^{+}(\mathbf{d}(\mathbf{M e O H}), m / z=401)$, $\mathrm{Al}(\mathrm{OTs}){ }_{3} \mathrm{H}^{+}(\mathbf{e}, m / z=541), \mathrm{Al}(\mathrm{OTs})_{3} \mathrm{H}\left(\mathrm{H}_{2} \mathrm{O}\right)^{+}\left(\mathbf{e}\left(\mathbf{H}_{2} \mathrm{O}\right), m / z=559\right)$, $\mathrm{Al}(\mathrm{OTs})_{3} \mathrm{H}(\mathrm{MeOH})^{+}(\mathbf{e}(\mathbf{M e O H}), m / z=573), \mathrm{Al}_{2}(\mathrm{OTs})_{4} \mathrm{OH}^{+}(\mathbf{f}, \mathrm{m} / z$ $=755)$, and $\mathrm{Al}_{2}(\mathrm{OTs})_{5}{ }^{+}$(g, $\left.m / z=909\right)$. All of these species are in good agreement with their calculated isotope distribution spectra (see ESI Fig. S2-S8†).

The ESI-MS results shown in Fig. 5 suggest that $\mathrm{Al}(\text { acac })_{3}$ reacts preferably with PTSA in $\mathrm{MeOH}$ to form $\mathrm{Al}(\mathrm{OTs})_{3}$, a Lewis acid. Yang et al. reported that $\mathrm{Al}(\mathrm{OTs})_{3}$ could be formed from $\mathrm{Al}_{2} \mathrm{O}_{3}$ and PTSA in water. ${ }^{17}$ Likewise, in the cooperative catalysis of $\mathrm{Al}$ compounds and PTSA, $\mathrm{Al}(\mathrm{OTs})_{3}$ would be in situ formed and act as a Lewis acid.

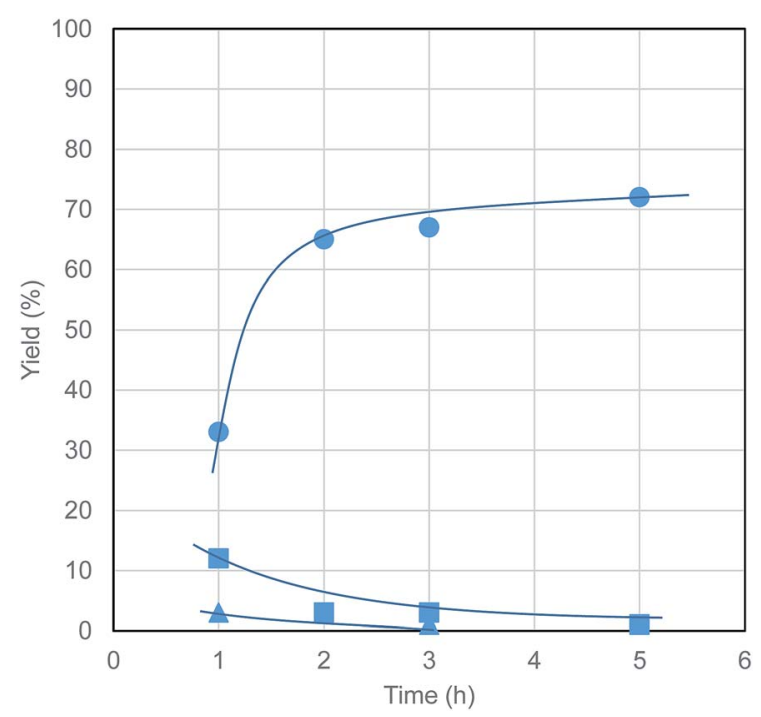

Fig. 3 Time course of MeLev formation from cellulose $\mathbf{0}=$ MeLev, $\boldsymbol{\Delta}$ $=$ MMF, $\boldsymbol{\square}=$ sugars. Conditions: $\mathrm{Al}(\mathrm{acac})_{3}(0.02 \mathrm{mmol}), \mathrm{PTSA}(0.20$ $\mathrm{mmol})$, microcrystalline cellulose $(405 \mathrm{mg}, 2.5 \mathrm{mmol}$ as glucose units), $\mathrm{MeOH}(20.0 \mathrm{~mL}), \mathrm{N}_{2}(0.5 \mathrm{MPa}), 180^{\circ} \mathrm{C}$. All the yields were determined by the same method described in Table 1. 


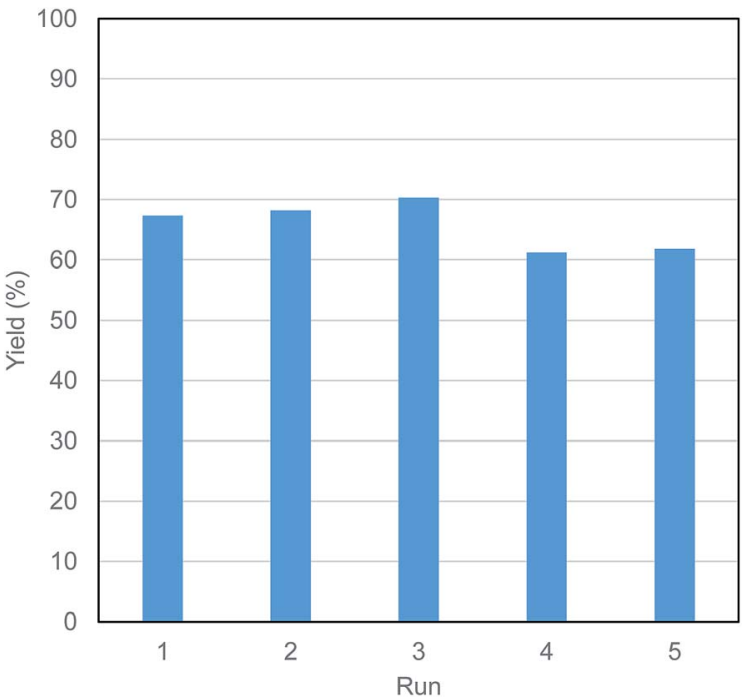

Fig. 4 Catalyst recyclability. Conditions: $\mathrm{Al}(\mathrm{acac})_{3}(0.02 \mathrm{mmol}), \mathrm{PTSA}$ $(0.20 \mathrm{mmol})$, microcrystalline cellulose $(405 \mathrm{mg}$ in each run, $2.5 \mathrm{mmol}$ as glucose units), $\mathrm{MeOH}(20.0 \mathrm{~mL}), \mathrm{N}_{2}(0.5 \mathrm{MPa}), 180{ }^{\circ} \mathrm{C}, 5 \mathrm{~h}$. The distilled residue was used as the catalyst for the next run without any treatment. All the yields were determined by the same method described in Table 1.

The effect of the Al/PTSA ratio (Fig. 1) shows that the formation of MeLev from cellulose is drastically enhanced by a very small amount of Al species in comparison with PTSA and that the yield of MeLev decreased as the Al/PTSA ratio increased.
These results suggest that the methanolysis of cellulose to sugars is mainly catalyzed by PTSA and that the main role of $\mathrm{Al}(\mathrm{OTs})_{3}$ lies in enhancing the formation of MeLev from sugars. To confirm this, we compared the reaction of glucose in $\mathrm{MeOH}$ using a catalyst system consisting of $\mathrm{Al}(\mathrm{acac})_{3}$ and PTSA (Al/ PTSA $=1 / 3$ ) with that using only PTSA (Table 2). The results show that the combination of $\mathrm{Al}(\mathrm{acac})_{3}$ and PTSA showed much higher catalytic activity for MeLev formation from glucose than PTSA alone.

A reaction mechanism can be proposed, as shown in Scheme 1. In the first step, cellulose is solvolyzed with methanol to produce sugars, catalyzed by the Brønsted acid PTSA. PTSA also reacts with $\mathrm{Al}$ precursors to form a Lewis acid, $\mathrm{Al}(\mathrm{OTs})_{3}$, which in combination with PTSA catalyze the conversion of sugars to MeLev via MMF. The cooperation of the Brønsted and

Table 2 Comparison of catalyst activities in reactions with glucose ${ }^{a}$

\begin{tabular}{|c|c|c|c|c|}
\hline \multirow[b]{2}{*}{ Entry } & \multirow[b]{2}{*}{ Catalyst } & \multicolumn{3}{|c|}{ Yield $^{b} / \%$} \\
\hline & & MeLev & MMF & Sugars $^{c}$ \\
\hline 1 & PTSA & 20 & - & 51 \\
\hline 2 & $\mathrm{Al}(\mathrm{acac})_{3}+\mathrm{PTSA}(\mathrm{Al} / \mathrm{PTSA}=1 / 3)$ & 62 & - & 11 \\
\hline
\end{tabular}

${ }^{a}$ Conditions: PTSA $(0.06 \mathrm{mmol}), \mathrm{Al}(\mathrm{acac})_{3}(0.02 \mathrm{mmol})$, glucose $(2.5$ $\mathrm{mmol}), \mathrm{MeOH}(20.0 \mathrm{~mL}), \mathrm{N}_{2}(0.5 \mathrm{MPa}), 180{ }^{\circ} \mathrm{C}, 5 \mathrm{~h} .{ }^{b}$ HPLC yields based on the amount of glucose. ${ }^{c}$ Total amount of fructose, glucose, and $\alpha$-methylglycoside.

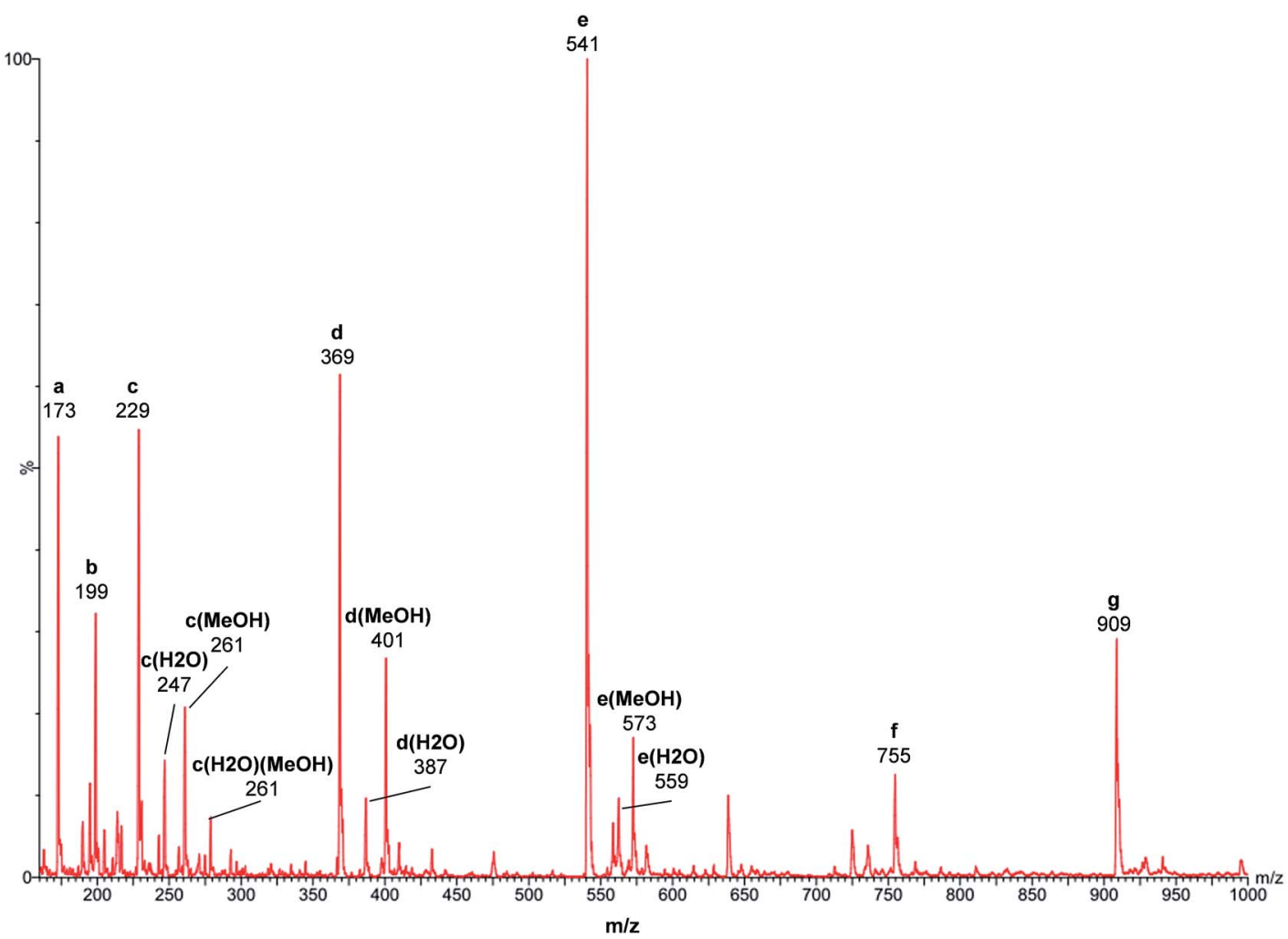

Fig. 5 ESI-MS spectrum of the catalyst species in MeOH. Sample: Al(acac) $3(0.02 \mathrm{mmol}), \mathrm{PTSA}(0.20 \mathrm{mmol}), \mathrm{MeOH}(20.0 \mathrm{~mL}), \mathrm{N}_{2}(0.5 \mathrm{MPa}), 180$ ${ }^{\circ} \mathrm{C}, 2 \mathrm{~h}$. 


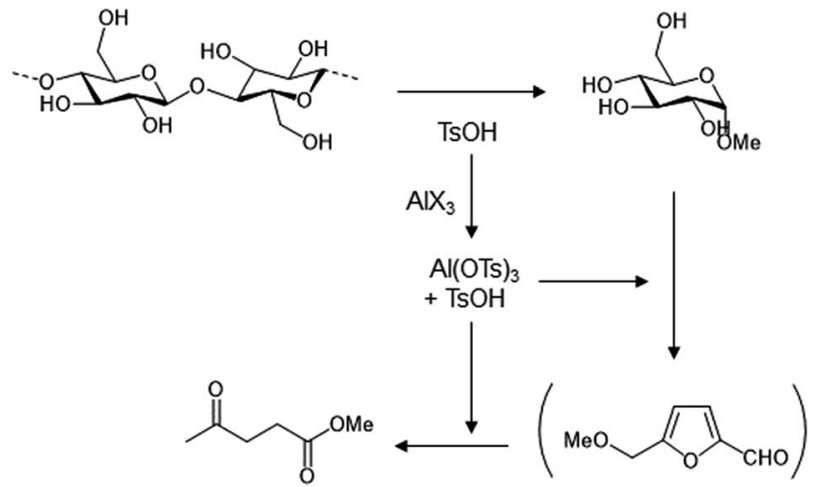

Scheme 1 A plausible reaction mechanism.

Lewis acids is responsible for the high yield of MeLev obtained from cellulose, as shown in our previous reports. ${ }^{14}$

It is well known that water molecules are closely associated with the cellulose matrix. ${ }^{18}$ When water is used as the solvent, such close interactions may inhibit the hydrolysis of cellulose with acid. In contrast, although little is known about the interaction of methanol in cellulose matrix, the proton affinity of methanol is much lower than that of water, making solvolysis of cellulose possible with a small amount of Brønsted acid in methanol. Li and Hu reported another effect of methanol; the formation of humin is suppressed due to protection of the aldehyde groups of glucose and hydroxymethylfurfural (HMF) by methanol. ${ }^{19}$ The same effect appeared to occur here, which would be responsible for the efficient transformation of cellulose to MeLev.

Finally, we applied the catalyst system to MeLev synthesis from actual wood biomass. The content of cellulose, hemicellulose, and lignin in the wood powders are shown in Table 3 and the results of MeLev synthesis from them are summarized in Table 4. Both cedar and eucalyptus powder were effectively converted to MeLev with a maximum yield of $80 \%$ based on the amount of cellulose in the wood powder with this catalyst system. These results suggest that the lignin component does not so inhibit catalysis. This catalyst system also works under a higher concentration of raw materials; in the presence of $10 \mathrm{wt} \%$ cedar powder, MeLev was formed in a maximum yield of $74 \%$. We also examined a scale-up experiment; under a ten times scaled-up condition using 10 wt $\%$ cedar powder, MeLev was confirmed to be formed in $72 \%$ yield (entry 5 , see ESI $\dagger$ ).

Table 3 Content of cellulose, hemicellulose, and lignin in wood powders (wt\%) ${ }^{a}$

\begin{tabular}{lll}
\hline & Cedar & Eucalyptus \\
\hline Cellulose & 43.6 & 44.7 \\
Hemicellulose & 36.4 & 40.0 \\
Lignin & 32.0 & 26.1
\end{tabular}

${ }^{a}$ Each of the contents were determined using the procedure shown in ref. 16.
Table 4 Reactions using wood powder

\begin{tabular}{llllll}
\hline & & \multicolumn{5}{c}{ Yield $^{c} \%$} \\
\cline { 5 - 6 } Entry & Raw material & Conc. $\left(\mathrm{g} \mathrm{L}^{-1}\right)$ & MeLev & MMF & Sugars $^{d}$ \\
\hline $1^{a}$ & Cedar & 25 & 80 & - & 5 \\
$2^{b}$ & Cedar & 100 & 74 & - & 1 \\
$3^{a}$ & Eucalyptus & 25 & 70 & - & 8 \\
$4^{b}$ & Eucalyptus & 100 & 63 & - & 2 \\
$5^{e}$ & Cedar & 100 & 72 & - & 3
\end{tabular}

${ }^{a}$ Conditions: $\mathrm{Al}(\mathrm{acac})_{3}(0.02 \mathrm{mmol})$, PTSA $(0.20 \mathrm{mmol})$, wood powder $(0.50 \mathrm{~g}), \mathrm{MeOH}(20.0 \mathrm{~mL}), \mathrm{N}_{2}(0.5 \mathrm{MPa}), 180{ }^{\circ} \mathrm{C}, 5$ h. ${ }^{b}$ Conditions: $\mathrm{Al}(\mathrm{acac})_{3}(0.08 \mathrm{mmol}), \mathrm{PTSA}(0.80 \mathrm{mmol})$, wood powder $(2.0 \mathrm{~g}), \mathrm{MeOH}$ $(20.0 \mathrm{~mL}), \mathrm{N}_{2}(0.5 \mathrm{MPa}), 180{ }^{\circ} \mathrm{C}, 5 \mathrm{~h} .{ }^{c}$ Based on the amount of glucose units in cellulose. ${ }^{d}$ Total amount of fructose, glucose, and $\alpha$ methylglycoside. ${ }^{e}$ Ten times scaled-up condition.

\section{Conclusions}

Based on the two hypotheses described in the Introduction, we developed a practical catalyst system for MeLev synthesis from wood biomass using Al compounds and PTSA; although it is inexpensive and simple, it affords a high yield of MeLev and is recyclable. According to hypothesis (1), the combination of different kinds of acids is effective for this reaction; the solvolysis of cellulose to sugars is catalyzed by Brønsted acidic PTSA and the conversion of sugars to MeLev is significantly enhanced by Lewis acidic $\mathrm{Al}(\mathrm{OTs})_{3}$ formed in situ from $\mathrm{Al}$ compounds and PTSA. Besides, according to hypothesis (2), $\mathrm{MeOH}$ is an efficient solvent for the MeLev synthesis from cellulose and cellulosic biomass. This is because of its lower affinity to cellulose and its function of protecting the highly reactive aldehyde groups of sugars and MMF to prevent undesirable humin formation.

\section{Acknowledgements}

This study was financially supported by the New Energy and Industrial Technology Development Organization (NEDO), Japan.

\section{Notes and references}

1 (a) T. Werpy and G. Petersen, Top Value Added Chemicals from Biomass. Volume I - Results of Screening for Potential Candidates from Sugars and Synthesis Gas, U. S. D. o. Energy, 2004; (b) J. J. Bozell and G. R. Petersen, Green Chem., 2010, 12, 539.

2 Recent reviews: (a) H. Kobayashi and A. Fukuoka, Green Chem., 2013, 15, 1740; (b) S. Van de Vyver, J. Geboers, P. A. Jacobs and B. F. Sels, ChemCatChem, 2011, 3, 82; (c) W. Deng, Q. Zhang and Y. Wang, Catal. Today, 2014, 234, 31; (d) S. Dutta and S. Pal, Biomass Bioenergy, 2014, 62, 182; (e) P. J. Deuss, K. Barta and J. G. de Vries, Catal. Sci. Technol., 2014, 4, 1174; (f) M. J. Climent, A. Corma and S. Iborra, Green Chem., 2014, 16, 516; $(g)$ F. H. Isikgor and C. Remzi Becer, Polym. Chem., 2015, 6, 4497; (h) 
A. Mukherjee, M. J. Dumont and V. Raghauan, Biomass Bioenergy, 2015, 72, 143.

3 J. J. Bozell, L. Moens, D. C. Elliott, Y. Wang, G. G. Neuenscwander, S. W. Fitzpatrick, R. J. Bilski and J. L. Jarnefeld, Resour., Conserv. Recycl., 2000, 28, 227.

4 L. E. Manzer, Appl. Catal., A, 2004, 272, 249.

5 (a) Y. Guo, K. Li and J. H. Clark, Green Chem., 2007, 9, 839; (b) Y. Guo, K. Li, X. Yu and J. H. Clark, Appl. Catal., B, 2008, 81, 182; (c) H.-F. Liu, F.-X. Zeng, L. Deng, B. Liao, H. Pang and Q.-X. Guo, Green Chem., 2013, 15, 81.

6 (a) J. Q. Bond, D. M. Alonso, D. Wang, R. M. West and J. A. Dumesic, Science, 2010, 327, 1110; (b) J. Q. Bond, D. Wang, D. M. Alonso and J. A. Dumesic, J. Catal., 2011, 281, 290.

7 (a) I. Podolean, V. Kuncser, N. Gheorghe, D. Macovei, V. I. Parvulescu and S. M. Coman, Green Chem., 2013, 15, 3077; (b) S. Dutta, L. Wu and M. Mascal, Green Chem., 2015, 17, 2335.

8 J.-P. Lange, J. Z. Vestering and J. Haan, Chem. Commun., 2007, 3488.

9 (a) J. Dahlmann, Chem. Ber., 1968, 101, 4251; (b) F. Camacho, P. González-Tello, E. Jurado and A. Robles, J. Chem. Technol. Biotechnol., 1996, 67, 350; (c) R. W. Torget, J. S. Kim and Y. Y. Lee, Ind. Eng. Chem. Res., 2000, 39, 2817; (d) J. S. Kim, Y. Y. Lee and R. W. Torget, Appl. Biochem. Biotechnol., 2001, 91, 331; (e) N. S. Mosier, A. Sarikaya, C. M. Ladisch and M. R. Ladisch, Biotechnol. Prog., 2001, 17, 474; (f) B. Girisuta, L. P. B. M. Janssen and H. J. Heeres, Ind. Eng. Chem. Res., 2007, 46, 1696.

10 (a) K. Seri, T. Sakaki, M. Shibata, Y. Inoue and H. Ishida, Bioresour. Technol., 2002, 81, 257; (b) L. Peng, L. Lin, J. Zhang, J. Zhuang, B. Zhang and Y. Gong, Molecules, 2010, 15, 5258; (c) F. H. Lv, R. Bi, Y. H. Liu, W. S. Li and X. P. Zhou, Catal. Commun., 2014, 49, 78; (d) L. Zhou,
H. Zou, J. Nan, L. Wu, X. Yang, Y. Su, T. Lu and J. Xu, Catal. Commun., 2014, 50, 13.

11 (a) Y. Ogasawara, S. Itagaki, K. Yamaguchi and N. Mizuno, ChemSusChem, 2011, 4, 519; (b) Z. Sun, M. Cheng, H. Li, T. Shi, M. Yuan, X. Wang and Z. Jiang, RSC Adv., 2012, 2, 9058; (c) F. Rataboul and N. Essayem, Ind. Eng. Chem. Res., 2011, 50, 799.

12 (a) J. Potvin, E. Sorlien, J. Hegner, B. DeBoef and B. L. Lucht, Tetrahedron Lett., 2011, 52, 5891; (b) S. Van de Vyver, J. Thomas, J. Geboers, S. Keyzer, M. Smet, W. Dehaen, P. A. Jacobs and B. F. Sels, Energy Environ. Sci., 2011, 4, 3601; (c) D. M. Alonso, J. M. R. Gallo, M. A. Mellmer, S. G. Wettstein and J. A. Dumesic, Catal. Sci. Technol., 2013, 3, 927; (d) D. Ding, J. Wang, J. Xi, X. Liu, G. Lu and Y. Wang, Green Chem., 2014, 16, 3846; (e) S. S. Joshi, A. D. Zodge, K. V. Pandare and B. D. Kulkarni, Ind. Eng. Chem. Res., 2014, 53, 18796; (f) Y. Zuo, Y. Zhang and Y. Fu, ChemCatChem, 2014, 6, 753; (g) D. Ding, J. Xi, J. Wang, X. Liu, G. Lu and Y. Wang, Green Chem., 2015, 17, 4037.

13 (a) Y. Nishiyama, P. Langan and H. Chanzy, J. Am. Chem. Soc., 2002, 124, 9074; (b) Y. Nishiyama, J. Sugiyama, H. Chanzy and P. Langan, J. Am. Chem. Soc., 2003, 125, 14300.

14 (a) K. Tominaga, A. Mori, Y. Fukushima, S. Shimada and K. Sato, Green Chem., 2011, 13, 810; (b) K. Nemoto, K. Tominaga and K. Sato, Chem. Lett., 2014, 43, 1327.

15 H. Zhu, Q. Cao, C. Li and X. Mu, Carbohydr. Res., 2011, 346, 2016.

16 Y. Teramoto, S. Lee and T. Endo, Bioresour. Technol., 2008, 99, 8856.

17 J. Yang and Y. Yuan, Catal. Lett., 2009, 131, 643.

18 H. Hatakeyama and T. Hatakeyama, Thermochim. Acta, 1998, 308, 3.

19 X. Hu and C.-Z. Li, Green Chem., 2011, 13, 1676. 